\title{
Exogenous Application of Bio-Regulators for Alleviation of Heat Stress in Seedlings of Maize
}

\author{
Yadav SK*, Pavan Kumar D, Tiwari YK, Jainender, Jyothi Lakshmi N, \\ Vanaja M and Maheswari M \\ ICAR-Central Research Institute for Dryland Agriculture, Hyderabad, Telangana, India
}

\section{Research Article}

Volume 2 Issue 3

Received Date: March 232017

Published Date: June 06, 2017

*Corresponding author: S.K Yadav, ICAR-Central Research Institute for Dryland Agriculture, Hyderabad, Telangana, 500059, India, E-mail: sushilyadav05@gmail.com

\section{Abstract}

High temperature is an important environmental stress that influences the growth and development of crop plants thus adversely affecting their production and productivity. An experiment was carried out to investigate the protective role of bioregulators viz., Putrescine (Put), Thiourea (TU) and Hydrogen Peroxide $\left(\mathrm{H}_{2} \mathrm{O}_{2}\right)$ against high temperature stress in maize at early vegetative stage. Maize genotypes earlier identified as heat tolerant (NSJ 221 and NSJ 189) and heat sensitive (RJR 270 and PSRJ 13099) were chosen for the present study. Independent foliar spray of Put (4 mM), TU $(20 \mathrm{mM})$ and $\mathrm{H}_{2} \mathrm{O}_{2}(1.2 \mathrm{mM})$ was observed to have significant difference $(\mathrm{P}>0.01)$ between genotypes, treatments and their interaction when applied 72 hrs prior to heat exposure. High temperature stress led to disruption of cellular membrane by increasing cell membrane injury, lipid peroxidation and $\mathrm{H}_{2} \mathrm{O}_{2}$ contents. It led to decrease in total chlorophyll content, soluble proteins, quantum yield and POD activity. Increased SOD activity in heat stressed seedlings was recorded with genotypes NSJ 189 and NSJ 221. Foliar application of Put, TU and $\mathrm{H}_{2} \mathrm{O}_{2}$ ameliorated heat-induced damages by stimulating the antioxidant enzyme system through decrease in lipid peroxidation, membrane injury and $\mathrm{H}_{2} \mathrm{O}_{2}$ contents in all the genotypes when compared with untreated heat stressed seedlings. Spray with these chemicals resulted in an increase in chlorophyll content, quantum yield and activities of anti-oxidative stress enzymes. Genotypes RJR 270 and PSRJ 13099 recorded improved heat tolerance with spray either of these chemicals by enhancing their biochemical potential. Spray of Put or TU was observed to be more effective of improving heat stress tolerance of maize seedlings.

Keywords: Anti-oxidative enzymes; Foliar spray; Maize; High temperature

\section{Introduction}

With increasing frequency of climate change and variability, plants are frequently subjected to various environmental stresses such as water deficit, freezing, heat and salt stress [1-7]. Temperature is an important environmental stress with both low and high temperatures affecting plant growth and development at whole plant level, tissue and cell level and even at subcellular level. High temperature induced a marked 


\section{Open Access Journal of Agricultural Research}

decrease, although variable, in growth of maize genotypes [8]. Elevated temperature caused substantial decrease in shoot dry mass, relative growth rate (RGR) and net assimilation rate (NAR) of maize [9]. Direct injuries due to high temperatures in plants include protein denaturation and their aggregation and increased fluidity of membrane lipids. Indirect injuries include inactivation of enzymes in chloroplast and mitochondria, inhibition of protein synthesis, protein degradation and loss of membrane integrity. High temperature induces numerous biochemical responses including increased production of reactive oxygen species (ROS) that disrupts normal metabolism of plants causing lipid peroxidation, protein denaturation and DNA damage [10,11]. ROS are harmful to all cellular compounds and negatively influence cellular metabolic processes. Nature has provided all the organisms with self repair mechanisms varying in extent to alleviate the damage by high temperature stress. The detoxification of these ROS is very important and plants have evolved complex strategies to deal with them. The plant cells typically respond to increases in ROS levels by increasing the expression and activity of ROS-scavenging enzymes and increasing the production of antioxidants in order to maintain redox homeostasis.

Plant stress tolerance can be improved with the exogenous use of stress alleviating chemicals. Some of the important plant bioregulators tested act in low concentrations to inhibit, promote or modify the morphological, physiological and biochemical processes of the plants. These substances can be applied directly to plant leaves, fruit and seed provoking alterations of vital and structural processes [12]. Previous research evidences suggested that exogenous application of Polyamines (di- and tri- and tetra-amines) regulate the enzyme activities and also be exploited for increasing tolerance to salinity, cold, drought, heavy metal, osmotic stress, high-temperature, water logging flooding tolerance and involved in nearly all developmental process in various crop plants [13]. These regulations may be attributed to the potential effect of putrescine (Put) which acts as free radical scavenger and plant cell membrane stabilizer [14]. Thiourea (TU) is a non-physiological thiol and has also been employed by various researchers to impart stress tolerance and improve yield of crops like wheat, mungbean, potato and maize [15-18].

Many stress alleviating agents including thiols are crucial for enhancing the crop productivity as they improve the metabolic imbalances produced in a cell during stress. Thiols are well-known to maintain the redox state (-SH/-S-S- ratio) of the cell and its proper functioning under stress conditions [19]. Improvement in plant growth and development under different stresses due to application of thiourea has been observed in crops like maize, wheat, pearl millet and cluster bean $[15,20$ 22]. Hydrogen peroxide $\left(\mathrm{H}_{2} \mathrm{O}_{2}\right)$ plays a key role in cellular signaling because of which it is also termed as a second messenger [23]. However, at higher levels, it causes oxidative stress thereby causing lipid peroxidation of biological membranes and leakage of ions. The production of $\mathrm{H}_{2} \mathrm{O}_{2}$ has been reported to rise in response to different biotic and abiotic stresses [5,24].

Exogenous application of diverse chemicals on different crop plants offers an effective strategy to mitigate various abiotic stresses in crop plants. In the present study, the selected bio-regulators have different characteristics which make them suitable choice for mitigating the damage induced by high temperature stress. Putrescine is also known to be a free radical scavenger and plant cell membrane stabilizer. Thiourea is a non-physiological thiol having a role in alleviating abiotic stress. $\mathrm{H}_{2} \mathrm{O}_{2}$ is a cellular signaling molecule and is also termed as secondary messenger. Manuscript describes the changes in various physiological and biochemical functions after spray of Put, TU and $\mathrm{H}_{2} \mathrm{O}_{2}$ on seedlings of tolerant and susceptible maize genotypes exposed to high temperature stress.

\section{Materials and Methods}

Maize genotypes identified earlier [25] as heat tolerant (NSJ 221 and NSJ 189) and heat susceptible (PSRJ 13099, RJR 270) were used in the present study. The seeds of these four maize genotypes were surface sterilized with $0.1 \% \mathrm{HgCl}_{2}$ for $1 \mathrm{~min}$, rinsed thoroughly with distilled water and sown in pots $(37 \mathrm{~cm}$ in diameter and $40 \mathrm{~cm}$ in height) filled with soil mixture containing red soil, sand and farm yard manure in 1:1:1 ratio. Forty eight pots were arranged in completely randomized block design (CRBD). Plants were observed daily and water was applied manually with the help of sprinkler whenever needed. However, precaution was taken to avoid excessive irrigation. A recommended dose of NPK was applied to all the treatments. Special attention was given to spacing between plants in pots in order to reduce plant competition and shade avoidance. After complete emergence, thinning was carried out leaving four seedlings per pot. Then, pots were divided into three sets; first set represented plants grown under normal conditions. Second set represented plants exposed to high 


\section{Open Access Journal of Agricultural Research}

temperature stress $\left(48^{\circ} \mathrm{C}\right.$ for $3 \mathrm{hrs}$ ) daily and third set had seedlings sprayed with Put (4 mM), TU $(20 \mathrm{mM})$ and $\mathrm{H}_{2} \mathrm{O}_{2}$ $(1.2 \mathrm{mM})$ and exposed to high temperature stress $\left(48^{\circ} \mathrm{C}\right.$ for $3 \mathrm{hrs}$ ) after 72 hours of spray. The experiment was conducted with three replications. To understand the possible effect of sprayed chemicals on various physiological and biochemical parameters, leaf samples were analyzed for membrane integrity, chlorophyll content, Fv/Fm and oxidative stress indicators (MDA, $\mathrm{H}_{2} \mathrm{O}_{2}$ ), total protein content and assay of activities of SOD and POD following standard procedures.

\section{Cell Membrane Injury (CMI)}

Membrane permeability was estimated by electrolyte leakage (EL) as described by Yadav et al., 2016 [24]. Leaves samples $(0.1 \mathrm{~g})$ were excised, washed with deionized water, and placed in test tubes containing $10 \mathrm{ml}$ distilled ionized water and incubated at room temperature for $1 \mathrm{hr}$ and subsequently at $4^{\circ} \mathrm{C}$ for next 24 hrs. The electrical conductivity of bathing solution (L1) was determined. The samples were then autoclaved at $120^{\circ} \mathrm{C}$ for $60 \mathrm{~min}$ to release all electrolytes, cooled to $25^{\circ} \mathrm{C}$ and the final electrical conductivity (L2) was determined. The EL was expressed following the formula EL= (L1/L2) $\times 100$.

\section{Malondialdehyde Content (MDA) or Lipid Peroxidation}

The level of lipid peroxidation was measured by determining the levels of malondialdehyde (MDA) content using the method of Hodges, et al. 1999 [26]. Leaf sample $(200 \mathrm{mg})$ was homogenized, in $10 \mathrm{ml}$ of $5 \%$ trichloroacetic acid (TCA). The homogenate was centrifuged at $15000 \mathrm{x}$ g for $10 \mathrm{~min}$. To a aliquot of $2.0 \mathrm{ml}$ supernatant, $4.0 \mathrm{ml}$ of $0.5 \%$ thiobarbaturic acid (TBA) in $20 \%$ TCA was added. The mixture was heated at $95^{\circ} \mathrm{C}$ for $30 \mathrm{~min}$ and then quickly cooled in an ice bath and centrifuged at $10000 \mathrm{x} \mathrm{g}$ for $10 \mathrm{~min}$. The absorbance of supernatant was recorded at $532 \mathrm{~nm}$ by spectrophotometer (Genesis 6). The value for non specific absorption at $600 \mathrm{~nm}$ was subtracted. The MDA content was calculated using its absorption coefficient of 155 $\mathrm{mmol}^{-1} \mathrm{~cm}^{-1}$ and expressed as $\mu \mathrm{mol}$ (MDA) $\mathrm{g}^{-1}$ dry weight.

\section{Hydrogen Peroxide $\left(\mathrm{H}_{2} \mathrm{O}_{2}\right)$}

The $\mathrm{H}_{2} \mathrm{O}_{2}$ concentration was determined as described by Velikova et al. (2000) [27]. Freshly cut leaf samples $(0.1 \mathrm{~g})$ were homogenized in an ice bath with $1 \mathrm{ml}$ of $0.1 \%$ $(\mathrm{w} / \mathrm{v})$ trichloroacetic acid (TCA) and centrifuged at $12,000 \mathrm{x} g$ for $15 \mathrm{~min}$. Supernatant $(0.5 \mathrm{ml})$ was added to
$10 \mathrm{mM}$ potassium phosphate buffer $(\mathrm{pH} 7.0)(0.5 \mathrm{ml})$ and $1 \mathrm{M}$ potassium iodide $(1 \mathrm{ml})$ and vortexed to mix the contents well. The absorbance was read at $390 \mathrm{~nm}$ using water as blank. The $\mathrm{H}_{2} \mathrm{O}_{2}$ concentration was determined from standard curve prepared by using $30 \% \mathrm{H}_{2} \mathrm{O}_{2}$.

\section{Determination of Chlorophyll Content}

Total chlorophyll content was extracted and estimated according to the method of Lichtenthaler (1987) [28]. About $0.2 \mathrm{~g}$ leaves was cut into tiny segments and kept in $10 \mathrm{ml}$ of chilled $80 \%$ acetone in a capped glass tube. After $48 \mathrm{~h}$ extraction in dark at $4^{\circ} \mathrm{C}$, the leaf segments were well-extracted for residual pigments. The total chlorophyll content was measured at 645 and 663 and pigment contents were calculated and expressed in mg g-1 FW.

Fv/Fm (Quantum Yield): Maximum Quantum yield, PSII photochemistry $\left(\mathrm{F}_{\mathrm{v}} / \mathrm{F}_{\mathrm{m}}\right)$ was measured by using Fluorpen (FluorPen FP 100) during noon hours.

Antioxidant Activity: Fresh leaf material (0.5 g) was ground in $10 \mathrm{~mL}$ of chilled phosphate buffer (pH 7.8) in an ice bath. The extract was filtered and centrifuged at $15,000 \times \mathrm{g}$ for $20 \mathrm{~min}$ at $4^{\circ} \mathrm{C}$. The supernatant was used for the determination of activity of antioxidant enzyme SOD and total soluble proteins.

Superoxide Dismutase (SOD): The activity of SOD was determined following Giannopolitis and Reis (1997) [29] on the basis of inhibition of photochemical reduction of nitro blue tetrazolium (NBT). The reaction mixture ( $3 \mathrm{ml})$ contained $50 \mu \mathrm{l}$ of enzyme extract with $50 \mu \mathrm{M}$ NBT, 1.3 $\mu \mathrm{M}$ riboflavin, $13 \mathrm{mM}$ methionine, $75 \mathrm{mM}$ EDTA and 50 $\mathrm{mM}$ phosphate buffer ( $\mathrm{pH}$ 7.8). The cuvettes containing samples were illuminated under $15 \mathrm{~W}$ fluorescence lamp light for $15 \mathrm{~min}$. The absorbance of the irradiated solution was recorded at $570 \mathrm{~nm}$ using a UV-visible spectrophotometer. One unit of SOD activity (U) was defined as the amount of enzyme required to cause $50 \%$ inhibition of the NBT photo reduction and expressed as U $\mathrm{mg}^{-1}$ protein.

Peroxidase (POD): Enzymes extraction was carried out by the homogenization of leaf samples $(0.5 \mathrm{~g})$ in $50 \mathrm{mM}$ Tris-buffer $(\mathrm{pH}, 7.5)$ containing $1 \%$ polyvinyl pyrrolidone. The extract was centrifuged at $10,000 \mathrm{~g}$ for $10 \mathrm{~min}$ at $4^{\circ} \mathrm{C}$ and the clear supernatant was used for peroxidase (POD) assay. Peroxidase activity was determined through Chance and Maehly (1955) [30] method by adding enzymes extract into reaction mixture, containing 


\section{Open Access Journal of Agricultural Research}

sodium-acetate buffer ( $\mathrm{pH} 5.4,50 \mathrm{mM})$, freshly prepared O-dianisidine solution $(0.5 \%)$ and $\mathrm{H}_{2} \mathrm{O}_{2}$. The increase in absorbance at every $15 \mathrm{sec}$ interval for $3 \mathrm{~min}$ was recorded using spectrophotometer (Genesys 6, Thermo Spectronic, USA) at $460 \mathrm{~nm}$. One POD unit was expressed as change in absorbance $\mathrm{U} \mathrm{mg}^{-1}$ protein and quantified.

\section{Protein Content}

The Bradford 1976 [31] method was employed to determine the soluble protein content in fresh leaf samples using Bovine Serum Albumin Fraction V as a standard.

\section{Statistical Analysis}

Experiment was laid out in complete randomized block design with three replications. Data was analyzed for analysis of variance by factorial complete randomized design and least significant differences (LSD) were calculated at 0.05 and 0.01 levels.

\section{Result and Discussion}

The results indicated that exogenous application of Put, TU and $\mathrm{H}_{2} \mathrm{O}_{2}$ resulted in an overall increase in improvement in heat stress tolerance in maize. Spray of these chemicals significantly increased antioxidant enzyme activity (SOD and POD), protein content and maintained the $\mathrm{Fv} / \mathrm{Fm}$ and chlorophyll content as compared to control. The factorial ANOVA analysis was highly significant $(\mathrm{P}>0.01)$ for all studied parameters. However, the response of tested genotypes was differential under heat stress conditions; NSJ 221 and NSJ
189 performed better under the high temperature stress than the genotypes PSRJ 13099 and RJR 270. Wide range

of studies on crop plants has shown an ample range of physiological and biochemical responses to heat stress. Only a few have explored how these processes are linked to heat resistance of the whole plant under field conditions. In the present study, both lipid peroxidation (MDA) and $\mathrm{H}_{2} \mathrm{O}_{2}$ contents increased upon exposure to heat stress (Figures $2 \& 3$ ) in all the genotypes.

Genotypes NSJ 221 and NSJ 189 showed minimum cell membrane injury (\%) and minimum changes in MDA contents indicating that they have a better protection mechanism to withstand oxidative stress caused by heat stress.

\section{Cell Membrane Stability}

Genetic variation among genotypes for membrane stability can be utilized to identify the tolerant and susceptible genotypes under heat-stressed environments. It is well evident that high temperature reduces cell membrane stability (CMS), genotypes showing high CMS are considered as tolerant. Higher CMS values indicated lower cell membrane injury (CMI) and hence higher ability to prevent the membrane protein denaturation, inhibition of electrolyte leakage and tolerance to prevailing heat stress [24]. High temperature stress led to increased cell membrane injury (CMI) in all the genotypes studied. Genotype PSRJ13099 sprayed with $\mathrm{H}_{2} \mathrm{O}_{2}$ showed least membrane injury followed by RJR 270 and NSJ 221 when sprayed with Put. CMS was higher in NSJ 189 and NSJ 221 under heat stress compared to RJR 270 and PSRJ 13099 (Table 1) (Figure 1).

\begin{tabular}{|c|c|c|c|c|c|}
\hline Treatments/genotypes & PSRJ 13099 & RJR 270 & NSJ 189 & NSJ 221 & Mean \\
\hline Control & $100.00 \pm 0.00 \mathrm{a}$ & $100.00 \pm 0.00 \mathrm{a}$ & $100.00 \pm 0.00 \mathrm{a}$ & $100.00 \pm 0.00 \mathrm{a}$ & 100 \\
\hline Heat stress & $45.04 \pm 1.09 \mathrm{j}$ & $40.74 \pm 1.14 \mathrm{i}$ & $63.07 \pm 0.93 \mathrm{k}$ & $59.66 \pm 0.52 \mathrm{i}$ & 52.13 \\
\hline $\mathrm{H}_{2} \mathrm{O}_{2}$ & $76.54 \pm 1.13 \mathrm{e}$ & $84.69 \pm 0.94 \mathrm{gh}$ & $69.64 \pm 1.03 \mathrm{c}$ & $66.48 \pm 2.29 \mathrm{~g}$ & 74.34 \\
\hline Putrescine & $72.79 \pm 0.68 \mathrm{ef}$ & $88.02 \pm 0.59 \mathrm{~d}$ & $80.57 \pm 0.66 \mathrm{~b}$ & $87.06 \pm 4.64 \mathrm{~cd}$ & 82.11 \\
\hline Thiourea & $69.95 \pm 0.48 \mathrm{fg}$ & $82.52 \pm 0.51 \mathrm{~h}$ & $64.78 \pm 0.26 \mathrm{c}$ & $83.10 \pm 0.82 \mathrm{~cd}$ & 75.09 \\
\hline Mean & 72.87 & 79.2 & 75.61 & 79.27 & \\
\hline \multicolumn{7}{|c|}{ SED CD $(0.05) \mathrm{CD}(0.01)$} \\
\hline Trenotypes 0.6934** $1.40144^{* *} 1.87527^{* *}$ \\
\hline \multicolumn{7}{|c|}{ Genotype x Treatments $1.55048^{* *} 3.13371^{* *} 4.19324^{* *}$} \\
\hline
\end{tabular}

Table 1: Effect of plant growth regulating chemicals on CMS (\%) of maize genotypes under high temperature stress. 


\section{Open Access Journal of Agricultural Research}

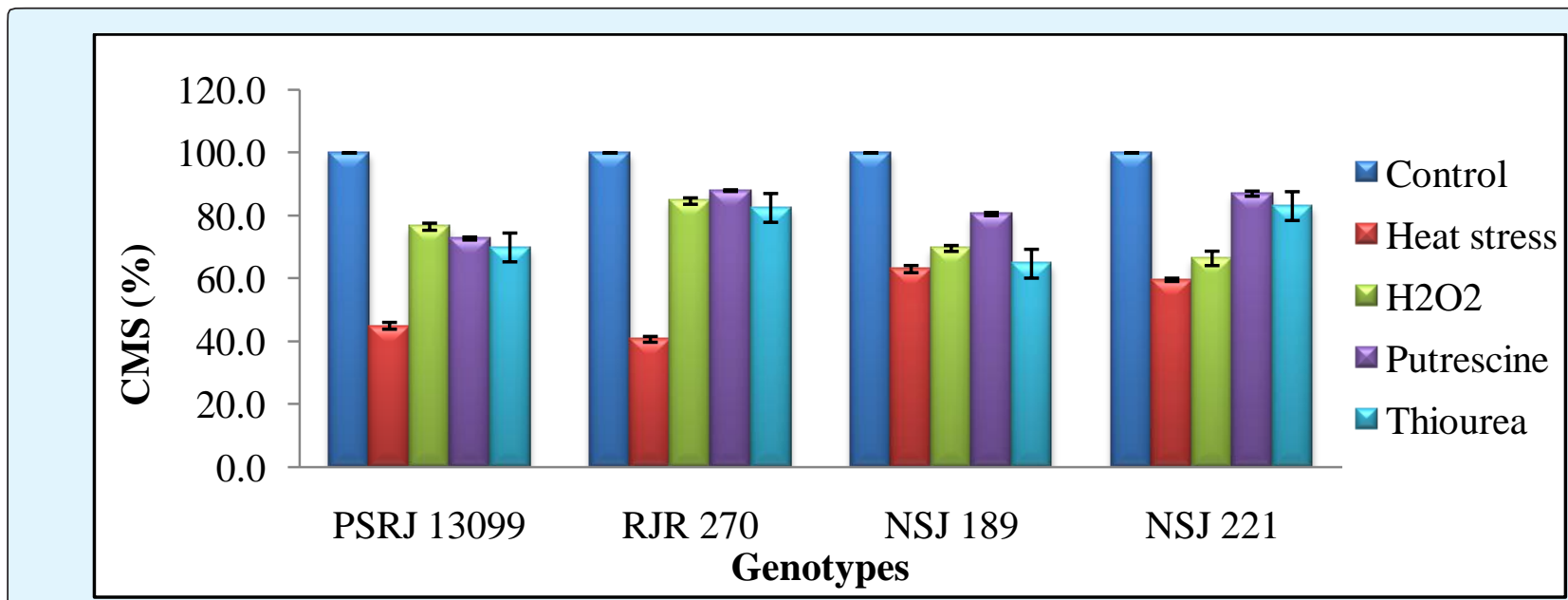

Figure 1: Effect of foliar application of $\mathrm{H}_{2} \mathrm{O}_{2}$, Putrescine and Thiourea on cell membrane stability (CMS \%) of maize seedlings exposed to high temperature stress

Sprays with Put, TU and $\mathrm{H}_{2} \mathrm{O}_{2}$ improved CMS in all the genotypes studied to varying extent. The improvement was more evident in RJR 270 and PSRJ 13099. Results indicated that $\mathrm{H}_{2} \mathrm{O}_{2}$ and putrescine acclimated seedlings had lower CMI for both susceptible and tolerant group of genotypes. These results were in agreement with Ranjeet, et al. 2014 [32]. Jiang \& Huang, 2000 [33] found that CMI led to more permeability to ions by increased solubilization and peroxidation of membrane lipids under heat stress. Cell membrane stability is now a well established index for screening crop plants against heat and drought tolerance. In the present study, high temperature stress induced damage in maize was observed to be associated with reduced membrane integrity and increased electrolyte leakage, indicating concurrence with previous reports of Shi et al., 2006; Bala et al., $2010[34,3]$.

\section{Lipid Peroxidation}

The level of lipid peroxidation, expressed as MDA content, has been described as an indicator of free radical damage of cell membranes. A sharp increase in MDA content was observed in the high temperature stressed seedlings of all the genotypes (Figure 2).

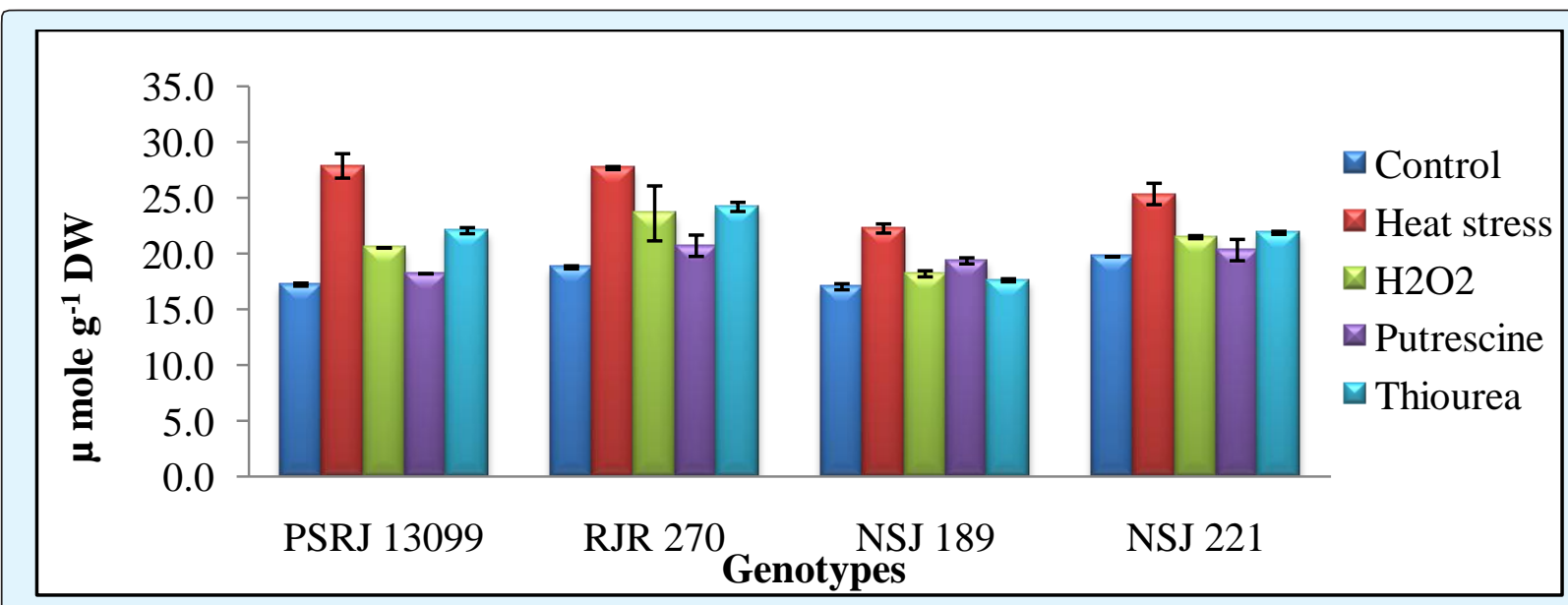

Figure 2: Effect of foliar application of $\mathrm{H}_{2} \mathrm{O}_{2}$, Putrescine and Thiourea lipid on peroxidation (MDA content) in maize seedlings exposed to high temperature stress. 


\section{Open Access Journal of Agricultural Research}

The contents of MDA decreased significantly in maize seedlings under all the foliar spray treatments when compared unsprayed controls. The decline of MDA content was more with foliar spray of Put followed by $\mathrm{H}_{2} \mathrm{O}_{2}$ and TU. Ranjeet et al., 2014 [32] reported that the combined treatment of heat stress with $2.5 \mathrm{mM}$ Put reduced MDA content and the results were in agreement with previous reports of Nayyar and Chander (2004) [35]. Polyamines act as antioxidants by inhibiting lipid peroxidation of plants [36]. At the cellular level, polyamine could mitigate the lipid peroxidation by down regulating the NAD (P) H-oxidase/NAD (P) H peroxidase activity. Also, lipid peroxidation decreased as a result of external supply of different concentrations of PAs on wheat [37]. Combined ANOVA showed highly significant $(\mathrm{P}>0.01)$ (Table 2) reduction in MDA content.

\begin{tabular}{|c|c|c|c|c|c|}
\hline Treatments/ Genotypes & PSRJ 13099 & RJR 270 & NSJ 189 & NSJ 221 & Mean \\
\hline Control & $17.23 \pm 0.14 \mathrm{kl}$ & $18.77 \pm 0.14 \mathrm{l}$ & $17.03 \pm 0.27 \mathrm{ijk}$ & $19.74 \pm 0.00 \mathrm{hij}$ & 18.19 \\
\hline Heat stress & $27.87 \pm 1.10 \mathrm{a}$ & $27.6 \pm 0.14 \mathrm{de}$ & $22.26 \pm 0.41 \mathrm{a}$ & $25.35 \pm 0.96 \mathrm{~b}$ & 25.77 \\
\hline $\mathrm{H}_{2} \mathrm{O}_{2}$ & $20.52 \pm 0.00 \mathrm{fgh}$ & $23.61 \pm 2.46 \mathrm{jkl}$ & $18.19 \pm 0.27 \mathrm{~cd}$ & $21.48 \pm 0.14 \mathrm{efg}$ & 20.95 \\
\hline Putrescine & $18.19 \pm 0.00 \mathrm{jkl}$ & $20.71 \pm 0.96 \mathrm{hij}$ & $19.35 \pm 0.27 \mathrm{efgh}$ & $20.32 \pm 0.96 \mathrm{ghi}$ & 19.64 \\
\hline Thiourea & $22.06 \pm 0.27 \mathrm{defg}$ & $24.19 \pm 0.41 \mathrm{kl}$ & $17.61 \pm 0.14 \mathrm{bc}$ & $21.87 \pm 0.14 \mathrm{efg}$ & 21.43 \\
\hline Mean & 21.17 & 22.99 & 18.89 & 21.75 & \\
\hline \multicolumn{7}{|c|}{ SED CD $(0.05) \mathrm{CD}(0.01)$} \\
\hline \multicolumn{7}{|c|}{ Treatments 0.42368** $0.85630^{* *} 1.14582^{* *}$} \\
\hline
\end{tabular}

Table 2: Effect of foliar application of plant growth regulating chemicals on MDA content ( $\mu$ mole ${ }^{-1}$ DW) of maize genotypes under high temperature stress.

Significantly lower oxidative stress was observed in plants sprayed with Put, TU and $\mathrm{H}_{2} \mathrm{O}_{2}$ and the results are in agreement with their possible role in quenching ROS and protecting the cells from lipid peroxidation [38]. Khalil et al., 2009 [39] reported that the high temperature stress decreased antioxidant enzymes activity leading to accumulation of $\mathrm{H}_{2} \mathrm{O}_{2}$ and consequently increased lipid peroxidation.

\begin{tabular}{|c|c|c|c|c|c|}
\hline Treatments/genotypes & PSRJ 13099 & RJR 270 & NSJ 189 & NSJ 221 & Mean \\
\hline Control & $53.12 \pm 7.68 \mathrm{i}$ & $41.76 \pm 3.67 \mathrm{j}$ & $77.17 \pm 5.01 \mathrm{e}$ & $83.85 \pm 5.01 \mathrm{~cd}$ & 63.98 \\
\hline Heat stress & $78.51 \pm 4.34 \mathrm{e}$ & $85.86 \pm 2.34 \mathrm{c}$ & $103.90 \pm 5.68 \mathrm{~b}$ & $119.93 \pm 3.01 \mathrm{a}$ & 97.05 \\
\hline $\mathrm{H}_{2} \mathrm{O}_{2}$ & $72.83 \pm 10.02 \mathrm{f}$ & $86.86 \pm 0.67 \mathrm{c}$ & $80.85 \pm 4.68 \mathrm{de}$ & $72.49 \pm 1.67 \mathrm{f}$ & 78.26 \\
\hline Putrescine & $36.75 \pm 2.00 \mathrm{k}$ & $67.82 \pm 1.67 \mathrm{~g}$ & $83.18 \pm 13.03 \mathrm{~cd}$ & $80.51 \pm 3.67 \mathrm{de}$ & 67.07 \\
\hline Thiourea & $61.47 \pm 1.34 \mathrm{~h}$ & $60.47 \pm 3.01 \mathrm{~h}$ & $57.80 \pm 1.67 \mathrm{~h}$ & $86.53 \pm 1.67 \mathrm{c}$ & 66.57 \\
\hline Mean & 60.53 & 68.55 & 80.58 & 88.66 & \\
\hline \multicolumn{7}{|c|}{ Genotypes $0.881^{* *} 1.780^{* *} 2.383^{* *}$} \\
\hline \multicolumn{7}{|c|}{ Treatments $0.985^{* *} 1.991^{* *} 2.664^{* *}$} \\
\hline \multicolumn{7}{|c|}{ Genotype x Treatments $1.970^{* *} 3.982^{* *} 5.328^{* *}$} \\
\hline
\end{tabular}

Table 3: Effect of foliar application of plant growth regulating chemicals on $\mathrm{H}_{2} \mathrm{O}_{2}$ content $(\mu$ mole g-1 DW) of maize genotypes under high temperature stress.

Highest induction of $\mathrm{H}_{2} \mathrm{O}_{2}$ was observed in NSJ 221 followed by NSJ 189 and within the treatments, the control seedlings recorded lowest values for $\mathrm{H}_{2} \mathrm{O}_{2}$ in $\mathrm{RJR}$

\section{Induction of $\mathrm{H}_{2} \mathrm{O}_{2}$ as a Signaling Molecule}

All the genotypes indicated an induction in $\mathrm{H}_{2} \mathrm{O}_{2}$ under high temperature stress conditions. The analysis of variance of genotypes, treatments and their interaction was highly significant at $(\mathrm{P}>0.01)$ level (Table 3$)$.
270 and PSRJ 13099. Application of $\mathrm{H}_{2} \mathrm{O}_{2}$, TU and Put led to alleviation of induction of $\mathrm{H}_{2} \mathrm{O}_{2}$ in all the genotypes (Figure 3). 


\section{Open Access Journal of Agricultural Research}

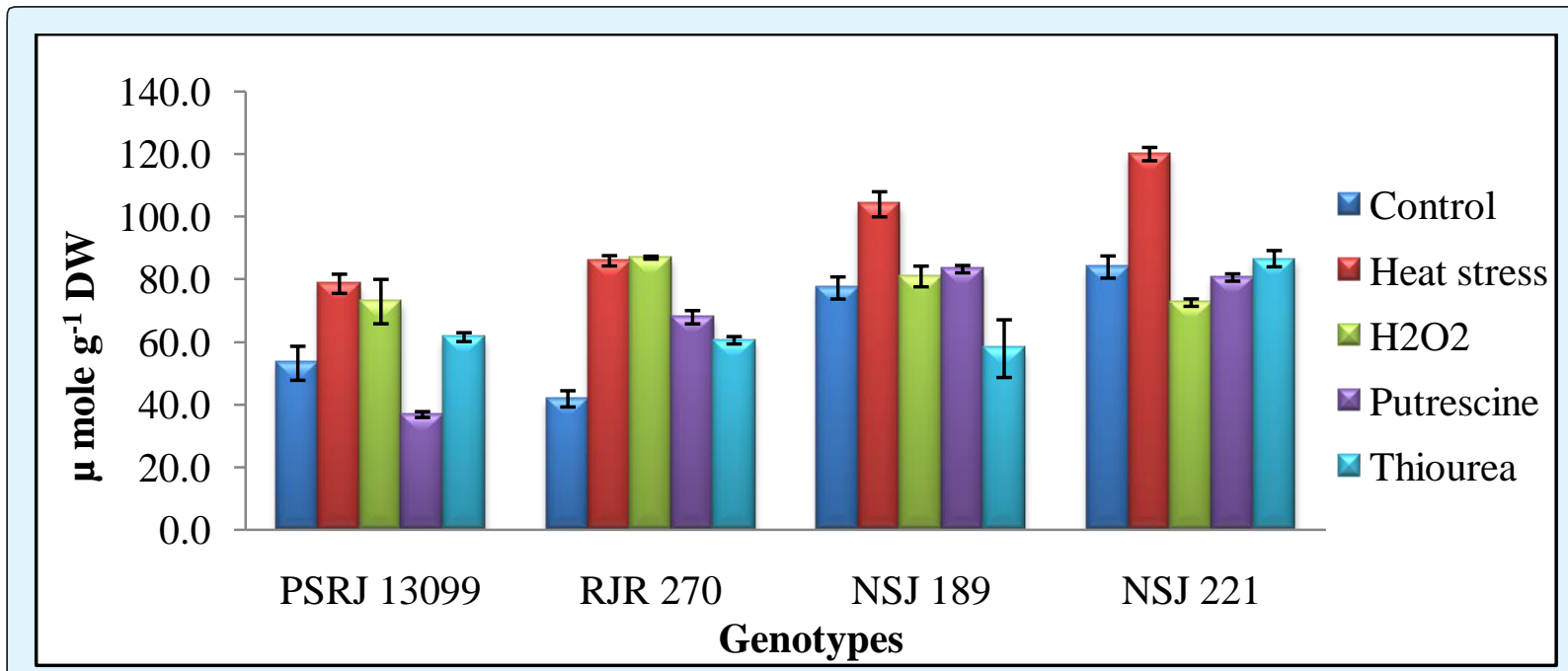

Figure 3: Effect of foliar application of $\mathrm{H}_{2} \mathrm{O}_{2}$, Putrescine and Thiourea foliar application on $\mathrm{H}_{2} \mathrm{O}_{2}$ accumulation in maize seedlings under high temperature stress.

$\mathrm{H}_{2} \mathrm{O}_{2}$ is the most important ROS generated in plants. Higher levels of $\mathrm{H}_{2} \mathrm{O}_{2}$ being toxicant, it has been regarded as an important regulator of the expression of some genes/proteins in cells [40]. According to Hernandez et al., 2000 [41], $\mathrm{H}_{2} \mathrm{O}_{2}$ control of expression of different genes which includes, antioxidant, cell defense, signaling, stress protein and transcription factors. $\mathrm{H}_{2} \mathrm{O}_{2}$ played a signaling role in triggering cross adaptation of maize seedling to various stresses [42]. Exogenous application of Polyamines has been shown to reduce the $\mathrm{H}_{2} \mathrm{O}_{2}$ levels and raise the levels of antioxidants in chickpea [35]. Ranjeet et al., 2014 [32] observed a decrease in $\mathrm{H}_{2} \mathrm{O}_{2}$ accumulation under heat stress combined with $2.5 \mathrm{mM}$ Put treatment.

\section{Chlorophyll Content}

The chlorophyll content in the seedlings of maize significantly decreased under heat stress when compared with control (Figure 4).

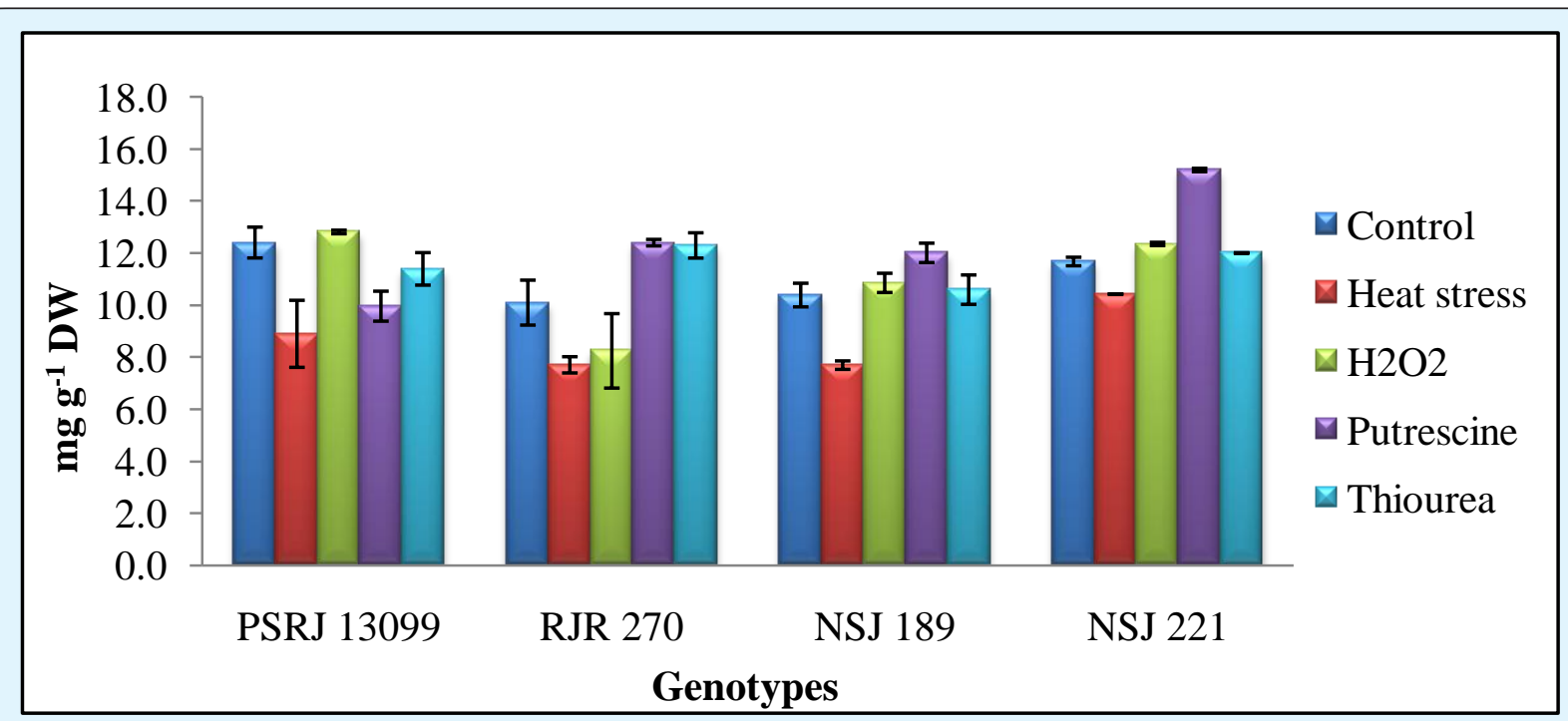

Figure 4: Effect of foliar application of $\mathrm{H}_{2} \mathrm{O}_{2}$, Putrescine and Thiourea on total chlorophyll content in maize seedlings exposed to high temperature stress. 


\section{Open Access Journal of Agricultural Research}

Exogenous application of Put, TU and $\mathrm{H}_{2} \mathrm{O}_{2}$ showed great protection effect on the chlorophyll content in the seedlings. Irrespective of genotypes, high temperature stressed maize seedlings sprayed with Put, TU and $\mathrm{H}_{2} \mathrm{O}_{2}$ invariably led to an improvement in chlorophyll content. According to mean values of genotypes, the tolerant genotype NSJ 221 recorded the maximum chlorophyll content of 12.32 followed by 11.08 in susceptible genotype PSRJ 13099 while the overall mean for genotypes was 10.96 . The mean values of treatments showed that the Put recorded the maximum chlorophyll content of 12.38 followed by 11.56 with TU. The interaction analysis of variance (Table 4) was highly significant and the chlorophyll content in NSJ 221 improved with Put treatment (15.19) followed by PSRJ 13099 sprayed with $\mathrm{H}_{2} \mathrm{O}_{2}(12.80)$.

\begin{tabular}{|c|c|c|c|c|c|}
\hline $\begin{array}{c}\text { Treatments/ } \\
\text { genotypes }\end{array}$ & PSRJ 13099 & RJR 270 & NSJ 189 & NSJ 221 & Mean \\
\hline Control & $12.40 \pm 0.59 \mathrm{bc}$ & $10.09 \pm 0.86 \mathrm{fgh}$ & $10.38 \pm 0.46 \mathrm{efg}$ & $11.67 \pm 0.16 \mathrm{bcde}$ & 11.14 \\
\hline Heat stress & $8.89 \pm 0.07 \mathrm{hg}$ & $7.69 \pm 0.31 \mathrm{~g}$ & $7.68 \pm 0.16 \mathrm{~g}$ & $10.41 \pm 0.01 \mathrm{efg}$ & 8.67 \\
\hline $\mathrm{H}_{2} \mathrm{O}_{2}$ & $12.80 \pm 0.07 \mathrm{~b}$ & $8.23 \pm 1.43 \mathrm{~g}$ & $10.84 \pm 0.37 \mathrm{defg}$ & $12.34 \pm 0.06 \mathrm{bc}$ & 11.05 \\
\hline Putrescine & $9.95 \pm 0.58 \mathrm{gh}$ & $12.39 \pm 0.13 \mathrm{bc}$ & $12.00 \pm 0.37 \mathrm{bcd}$ & $15.19 \pm 0.06 \mathrm{ab}$ & 12.38 \\
\hline Thiourea & $11.38 \pm 0.63 \mathrm{cdef}$ & $12.28 \pm 0.49 \mathrm{bc}$ & $10.58 \pm 0.57 \mathrm{efg}$ & $11.99 \pm 0.01 \mathrm{~cd}$ & 11.56 \\
\hline Mean & 11.08 & 10.14 & 10.3 & 12.32 & \\
\hline \multicolumn{7}{|c|}{ SED CD $(0.05) \mathrm{CD}(0.01)$} \\
\hline \multicolumn{7}{|c|}{ Treatmpents $0.300^{* *} 0.606^{* *} 0.811^{* *}$} & $0.678^{* *} 0.907^{* *}$ \\
\hline \multicolumn{7}{|c|}{ Genotype x Treatments $0.671^{* *} 1.356^{* *} 1.814^{* *}$} \\
\hline
\end{tabular}

Table 4: Effect of foliar application of plant growth regulating chemicals on chlorophyll content (mg $\mathrm{g}^{-1} \mathrm{DW}$ ) of maize genotypes under high temperature stress.

Our results conclude that the foliar spray of these chemicals showed significant improvement in chlorophyll content. Sharma et al. (2008) [43] reported an increase in chlorophyll content along with other yield attributes in wheat with use of bio-regulators and thiourea foliar spray. Emmanuel et al. (2010) [44] reported an increase in chlorophyll content due to treatment of rare earth elements in wheat. Heat stress led to decrease in chlorophyll content and similar results have been obtained earlier by Morales et al., 2003 [45]. Garg (2003)
[4] has shown that photosynthetic efficiency of thiourea applied plants was better in mung bean with higher contents of total chlorophyll as compared to the control.

\section{Quantum Yield and ROS Generation}

The maximal quantum yield of PSII photochemistry, Fv/Fm was significantly reduced under heat stress for all the genotypes, which was up to $84 \%$ lower than the control (Table 5).

\begin{tabular}{|c|c|c|c|c|c|}
\hline $\begin{array}{c}\text { Treatments/ } \\
\text { genotypes }\end{array}$ & PSRJ 13099 & RJR 270 & NSJ 189 & NSJ 221 & Mean \\
\hline Control & $0.793 \pm 0.01 \mathrm{a}$ & $0.692 \pm 0.02 \mathrm{~b}$ & $0.793 \pm 0.01 \mathrm{~b}$ & $0.758 \pm 0.02 \mathrm{a}$ & 0.76 \\
\hline Heat stress & $0.033 \pm 0.02 \mathrm{~h}$ & $0.045 \pm 0.07 \mathrm{~h}$ & $0.120 \pm 0.04 \mathrm{~h}$ & $0.260 \pm 0.05 \mathrm{~h}$ & 0.11 \\
\hline $\mathrm{H}_{2} \mathrm{O}_{2}$ & $0.328 \pm 0.04 \mathrm{ef}$ & $0.242 \pm 0.01 \mathrm{fg}$ & $0.230 \pm 0.08 \mathrm{fg}$ & $0.460 \pm 0.02 \mathrm{~g}$ & 0.32 \\
\hline Putrescine & $0.408 \pm 0.10 \mathrm{cde}$ & $0.212 \pm 0.04 \mathrm{~g}$ & $0.370 \pm 0.04 \mathrm{~g}$ & $0.603 \pm 0.09 \mathrm{de}$ & 0.4 \\
\hline Thiourea & $0.443 \pm 0.12 \mathrm{~cd}$ & $0.243 \pm 0.01 \mathrm{fg}$ & $0.260 \pm 0.09 \mathrm{fg}$ & $0.490 \pm 0.08 \mathrm{c}$ & 0.36 \\
\hline Mean & 0.401 & 0.286 & 0.355 & 0.514 & \\
\hline \multicolumn{7}{|c|}{ Senotypes $0.019^{* *} 0.039^{* *} 0.052^{* *}$} \\
\hline \multicolumn{7}{|c|}{ Treatments $0.022^{* *} 0.044^{* *} 0.058^{* *}$} \\
\hline \multicolumn{7}{|c|}{ Genotype x Treatments $0.043^{*} 0.087^{*} 0.117^{*}$} \\
\hline
\end{tabular}

Table 5: Effect of foliar application of plant growth regulating chemicals on Fv/Fm (quantum yield) of maize genotypes under high temperature stress. 


\section{Open Access Journal of Agricultural Research}

However, the decline in Fv/Fm was significantly alleviated by foliar application of Put which maintained the $\mathrm{Fv} / \mathrm{Fm}$ at the 0.40 level as compared to non-stressed control (0.76). TU treated seedlings maintained $\mathrm{Fv} / \mathrm{Fm}$ at 0.36 . However, the parameter $\mathrm{Fv} / \mathrm{Fm}$ was not able to recover to the control level in any of the foliar sprayed seedlings. The mean values of genotypes showed that, NSJ 211 had maximum Fv/Fm of 0.51 followed by PSRJ 13099 (0.40). Two factorial ANOVA of genotypes and treatments were highly significant at $\mathrm{P}>0.01$ level. The control seedlings with all the genotypes showed higher Fv/Fm values. The highest value of 0.80 was recorded by NSJ 189 and for rest of the genotypes descending order was PSRJ 13099>NSJ 221> RJR 270. The Fv/Fm improved adequately in NSJ 221 with Put (0.60), TU (0.49) and $\mathrm{H}_{2} \mathrm{O}_{2}$ (0.46). Photosystem-II (PSII) is most sensitive to high temperature [46]. Asada, (2006) [2] suggested that heat stress uncoupled enzymes and metabolic pathways leading to the generation and accumulation of unwanted and harmful ROS most commonly singlet oxygen $\left({ }^{1} \mathrm{O}_{2}\right)$, superoxide radical $\left(\mathrm{O}_{2}{ }^{-}\right)$, hydrogen peroxide $\left(\mathrm{H}_{2} \mathrm{O}_{2}\right)$ and hydroxyl radical $\left(\mathrm{OH}^{\cdot}\right)$ which were responsible for oxidative stress. The reaction centers of PSI and PSII in chloroplasts were the major sites of ROS generation, though ROS were also generated in other organelles viz. peroxisomes and mitochondria [6]. A linear relationship exists between maximal efficiency of PSII and the accumulated ROS (Figure 5) (Table 6).

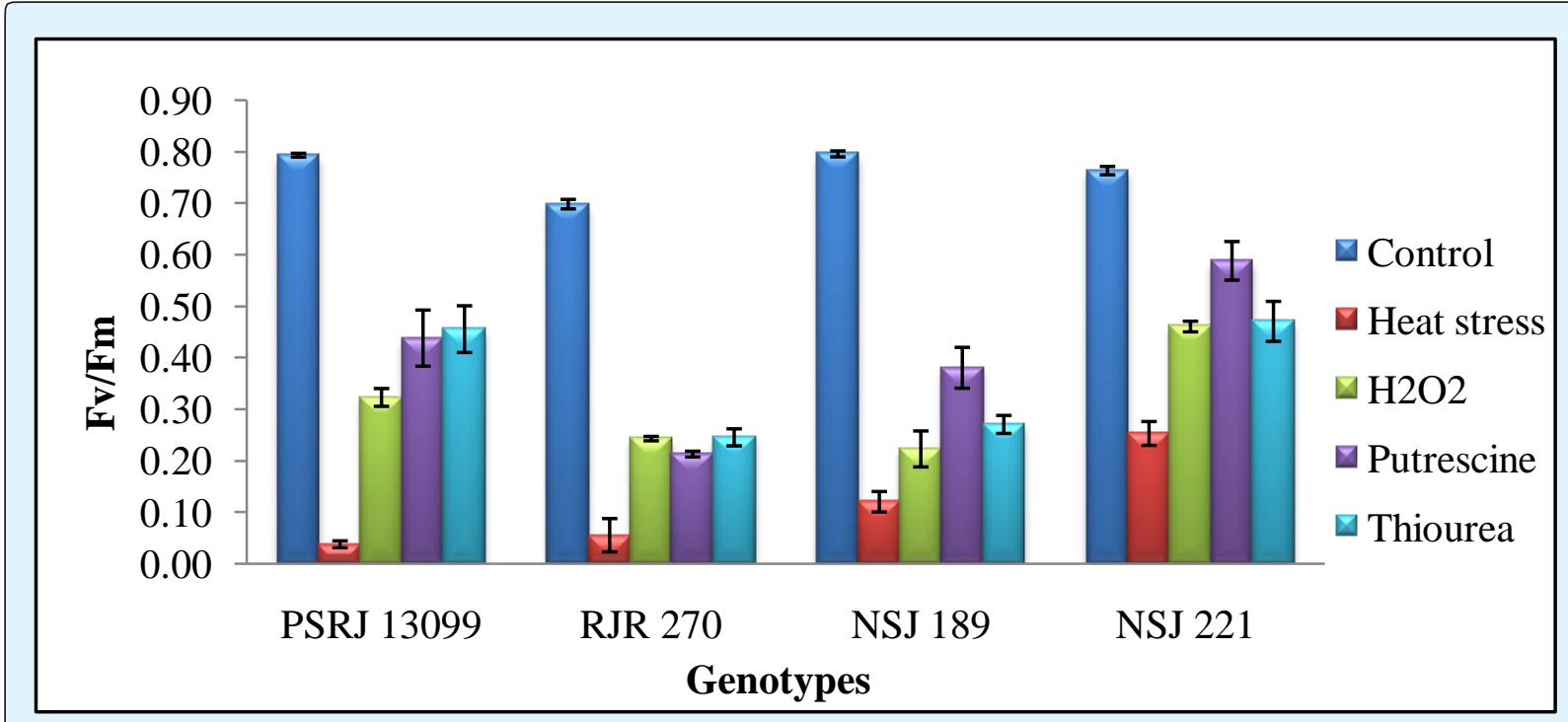

Figure 5: Effect of foliar application of $\mathrm{H}_{2} \mathrm{O}_{2}$, Putrescine and Thiourea on Quantum Yield Photosystem II photochemistry (Fv/Fm) in maize seedlings exposed to high temperature stress.

\begin{tabular}{|c|c|c|c|c|c|}
\hline $\begin{array}{c}\text { Treatments/ } \\
\text { genotypes }\end{array}$ & PSRJ 13099 & RJR 270 & NSJ 189 & NSJ 221 & Mean \\
\hline Control & $88.86 \pm 3.06 \mathrm{c}$ & $79.18 \pm 1.42 \mathrm{e}$ & $79.37 \pm 2.49 \mathrm{e}$ & $55.81 \pm 0.24 \mathrm{i}$ & 75.81 \\
\hline Heat stress & $68.71 \pm 1.33 \mathrm{~d}$ & $55.52 \pm 3.14 \mathrm{ei}$ & $89.45 \pm 1.48 \mathrm{~cd}$ & $73.54 \pm 0.38 \mathrm{f}$ & 71.81 \\
\hline $\mathrm{H}_{2} \mathrm{O}_{2}$ & $98.27 \pm 0.83 \mathrm{~b}$ & $78.61 \pm 6.04 \mathrm{e}$ & $75.04 \pm 2.91 \mathrm{f}$ & $61.76 \pm 2.95 \mathrm{~h}$ & 78.41 \\
\hline Putrescine & $90.94 \pm 2.62 \mathrm{c}$ & $70.04 \pm 7.08 \mathrm{~g}$ & $97.19 \pm 1.25 \mathrm{~b}$ & $73.48 \pm 1.88 \mathrm{f}$ & 82.91 \\
\hline Thiourea & $79.66 \pm 1.08 \mathrm{e}$ & $80.18 \pm 1.37 \mathrm{e}$ & $102.06 \pm 0.00 \mathrm{a}$ & $72.66 \pm 3.10 \mathrm{fg}$ & 83.64 \\
\hline Mean & 85.29 & 72.7 & 88.62 & 67.45 & \\
\hline \multicolumn{7}{|c|}{ SED CD $(0.05) \mathrm{CD}^{\prime}(0.01)$} \\
\hline \multicolumn{7}{|c|}{ Treatments $0.742^{* *} 1.342^{* *} 1.795^{* *}$} \\
\hline \multicolumn{7}{|c|}{ Genotype x Treatments $1.485^{* *} 3.000^{* *} 4.015^{* *}$} \\
\hline
\end{tabular}

Table 6: Effect of foliar application of plant growth regulating chemicals on the activity of SOD (U mg-1 Protein) of maize genotypes under high temperature stress. 


\section{Open Access Journal of Agricultural Research}

\section{Antioxidant Enzymes SOD and POD as Scavengers of ROS:}

Excessive ROS production can cause oxidative stress, which damages plant metabolism at various levels. ROSscavenging antioxidant enzymes, such as SOD and POD, play a vital role in removing these destructive oxidant species. By catalyzing the detoxification of $\mathrm{O}_{2} \cdot-$ to $\mathrm{O}_{2}$ and $\mathrm{H}_{2} \mathrm{O}_{2}$, SOD inhibits cell damage caused by $\mathrm{O}_{2}-{ }^{--}$. POD break down $\mathrm{H}_{2} \mathrm{O}_{2}$ to $\mathrm{H}_{2} \mathrm{O}$ and $\mathrm{O}_{2}$. When plants are exposed to oxidative stress, antioxidant systems become active and begin to scavenge ROS. Antioxidant defense system play vital role in helping plants tolerate stressful conditions. Highly significant changes in SOD and POD activities were observed in seedlings of all the genotypes sprayed with various bio-regulators $(\mathrm{P}>0.01)$ (Figure 6).

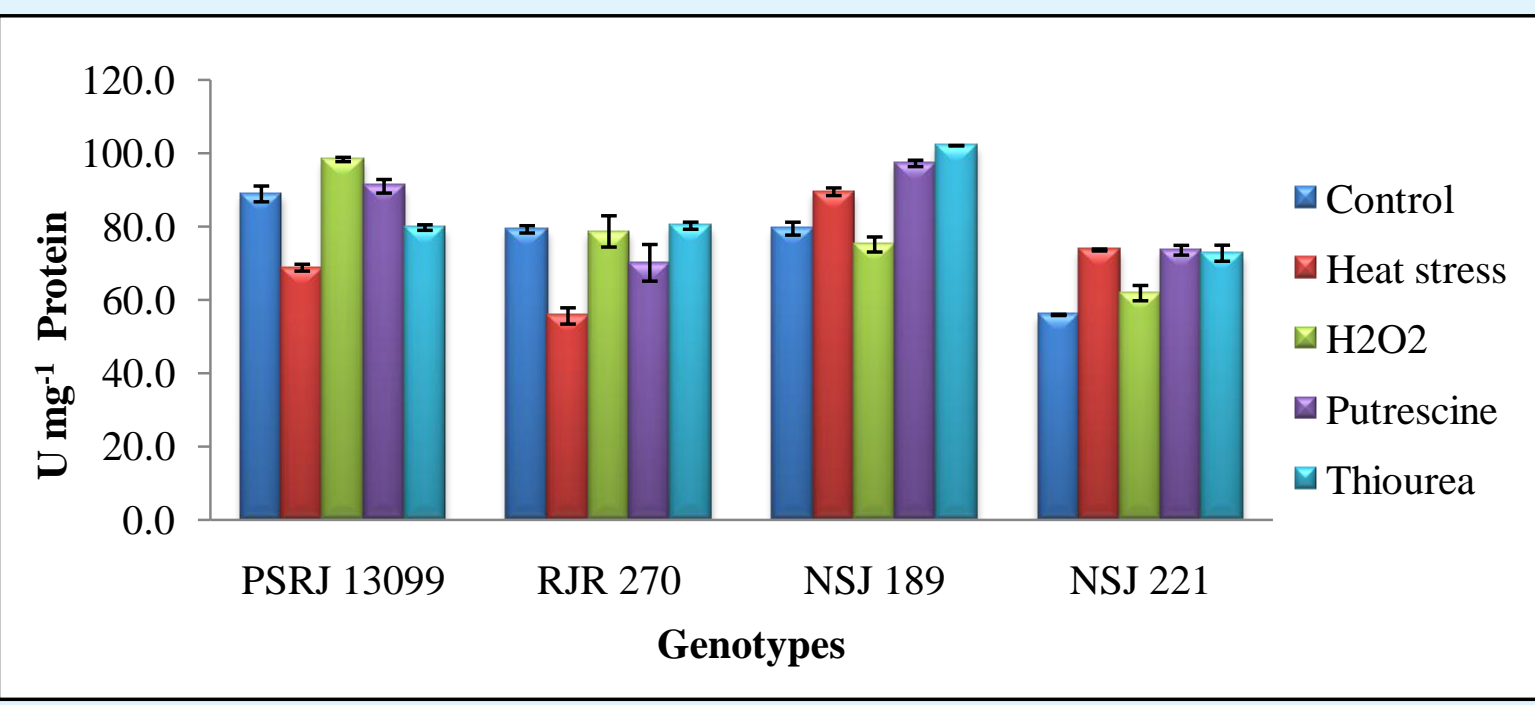

Figure 6: Quantification of SOD enzyme activity in maize seedlings upon exposure to high temperature stress. Prior to heat exposure seedlings were treated with $\mathrm{H}_{2} \mathrm{O}_{2}$, Putrescine and Thiourea foliar application.

High temperature stress led to an increase in SOD activity in stressed seedlings of tolerant genotypes NSJ 189 and NSJ 221 as compared to respective controls whereas a decrease in activity was observed in susceptible genotypes, PSRJ 13099 and RJR 270. Susceptible genotypes sprayed with various bioregulators exhibited better SOD activity. Interaction analysis of variance showed significant increase in the activity of SOD in NSJ 189 treated with TU followed by Put. Foliar application of different chemicals improved SOD activity in all the genotypes under high temperature stress and net improvement was in the order of NSJ $189>$ PSRJ 13099> RJR 270>NSJ 221 and for treatments, it was TU> Put $>\mathrm{H}_{2} \mathrm{O}_{2}>$ Control> Heat stress. Results indicated that the genotype NSJ 221 may have natural resistance towards heat stress which might be the reason for least generation of ROS under heat stress. Ranjeet et al. (2014) [32] found that SOD activity was higher in response to heat stress alone and combined treatment of heat stress and Put. The results are positively correlating with the lowest MDA content of the genotype NSJ 221. The differences between genotypes regarding the enzyme activity and other parameters studied varied significantly which might be due to genotypic specificity or variation. According to Chakraborty and Pradhan, 2011 [47], the activities of enzymes also differ depending upon tolerance or susceptibility of different crop varieties, their growth stages and growing season.

Irrespective of genotypes, foliar spray on maize seedling with Put, TU and $\mathrm{H}_{2} \mathrm{O}_{2}$ at 72 hrs before high temperature treatment $\left(48^{\circ} \mathrm{C}\right.$ for $\left.3 \mathrm{hrs}\right)$ resulted in the maximum increase in POD activity compared with controls and heat stressed seedlings respectively, (Figure 7) (Table 7). 


\section{Open Access Journal of Agricultural Research}

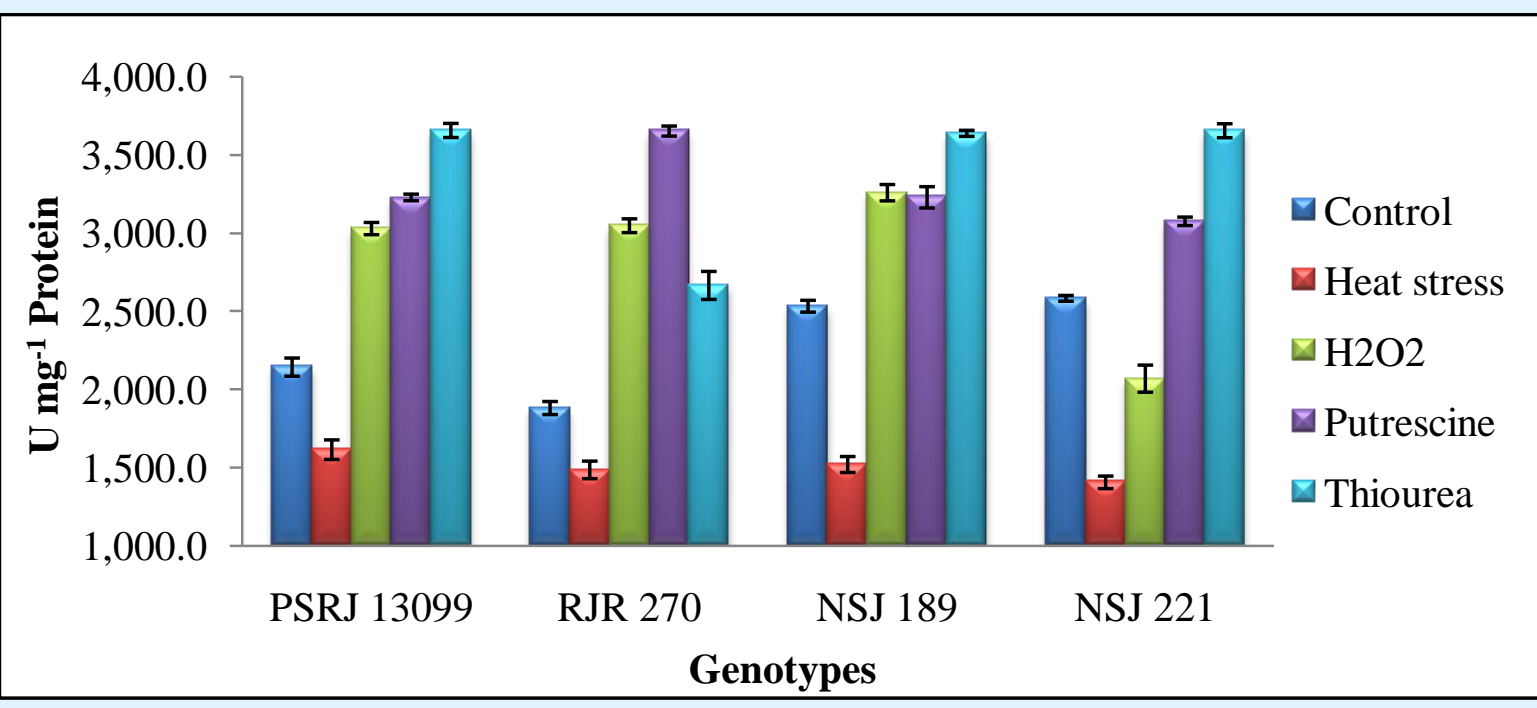

Figure 7: Quantification of peroxidase (POD) activity in maize seedlings upon exposure to high temperature stress. Prior to heat exposure seedlings were treated with $\mathrm{H}_{2} \mathrm{O}_{2}$, Putrescine and Thiourea foliar application.

\begin{tabular}{|c|c|c|c|c|c|}
\hline $\begin{array}{c}\text { Treatments/ } \\
\text { genotypes }\end{array}$ & PSRJ 13099 & RJR 270 & NSJ 189 & NSJ 221 & Mean \\
\hline Control & $2143.04 \pm 82.18 \mathrm{f}$ & $1881.25 \pm 58.96 \mathrm{~g}$ & $2532.32 \pm 53.62 \mathrm{e}$ & $2582.88 \pm 26.08 \mathrm{de}$ & 2284.87 \\
\hline Heat stress & $1614.68 \pm 88.53 \mathrm{~h}$ & $1485.40 \pm 79.50 \mathrm{i}$ & $1519.78 \pm 72.39 \mathrm{~h} \mathrm{i}$ & $1405.83 \pm 56.67 \mathrm{i}$ & 1506.42 \\
\hline $\mathrm{H}_{2} \mathrm{O}_{2}$ & $3029.03 \pm 55.19 \mathrm{c}$ & $3047.28 \pm 62.34 \mathrm{c}$ & $3258.52 \pm 73.88 \mathrm{~b}$ & $2069.11 \pm 122.37 \mathrm{f}$ & 2850.98 \\
\hline Putrescine & $3228.27 \pm 63.63 \mathrm{~b}$ & $3652.79 \pm 126.75 \mathrm{a}$ & $3228.79 \pm 27.41 \mathrm{~b}$ & $3075.44 \pm 62.99 \mathrm{c}$ & 3296.32 \\
\hline Thiourea & $3656.66 \pm 29.90 \mathrm{a}$ & $2665.35 \pm 45.36 \mathrm{~d}$ & $3638.12 \pm 96.53 \mathrm{ab}$ & $3654.85 \pm 38.25 \mathrm{a}$ & 3403.74 \\
\hline Mean & 2734.34 & 2546.41 & 2835.5 & 2557.62 & \\
\hline \multicolumn{7}{|c|}{ SED CD $(0.05) \mathrm{CD}^{2}(0.01)$} \\
\hline \multicolumn{7}{|c|}{ Treatments $29.12^{* *} 52.79^{* *} 70.64^{* *} 52^{* *} 78.97^{* *}$} \\
\hline \multicolumn{7}{|c|}{ Genotype x Treatments $58.40^{* *} 118.04^{* *} 157.95^{* *}$} \\
\hline
\end{tabular}

Table 7: Effect of foliar application of plant growth regulating chemicals on POD (U mg-1 Protein) of maize genotypes under high temperature stress.

Application of $4 \mathrm{mM}$ Put produced the highest increase in the activity of POD in RJR 270 followed by $20 \mathrm{mM}$ TU in PSRJ 13099. The genotype mean values showed a greater improvement of POD activity in NSJ 189 followed by PSRJ 13099 and NSJ 221. Tolerant genotypes (NSJ 221 and NSJ 189) showed high POD activity in control seedlings when compared with susceptible genotypes. Here it may be inferred that tolerant genotypes can endure heat stress because they possess natural tolerance. Little improvement in POD activity with spray treatments might be enough to withstand the stressed conditions. Bavita and Akash (2011) [48] observed that high temperature led to increase in POD activity in both root and shoot and it was higher in sprayed samples. It has been reported that the abiotic stresses cause increase in the production of reactive oxygen species, ionic imbalance, damage to membranes and macromolecules [49]. PAs play an important role in regulation of these processes [50]. Interaction of different stresses might increase the cellular concentration of ROS, which was finally converted to $\mathrm{H}_{2} \mathrm{O}_{2}$ [51]. The results of the present study explain how the stressed seedlings treated with TU and Put had enhanced SOD and POD activities, indicating that there was efficient ROS scavenging activity in the treated seedlings. The combined action of SOD and POD efficiently eliminated superoxide and hydrogen peroxide and 


\section{Open Access Journal of Agricultural Research}

indirectly protected plants against toxic hydroxyl radicals. These results are in accordance with Almeselmani et al. (2009) [1] who observed that the activities of SOD, APX, CAT, GR, and POX increased significantly at all stages of growth in heat tolerant cultivars of wheat plants in response to heat stress treatment. TU is able to facilitate the biosynthesis of antioxidant enzymes. The alleviation of oxidative damage by using thiourea appears to be due to the presence of a thiol group [52], which is very important in the scavenging of reactive oxygen species.
Looking at the structure of thiourea, both "imino" and "thiol" functional groups have great implications in abiotic stress tolerance.

\section{Level of Soluble Proteins}

The mean values of data (Table 8) showed that highest protein content was recorded in genotype PSRJ 13099 followed by NSJ 221 (Figure 8).

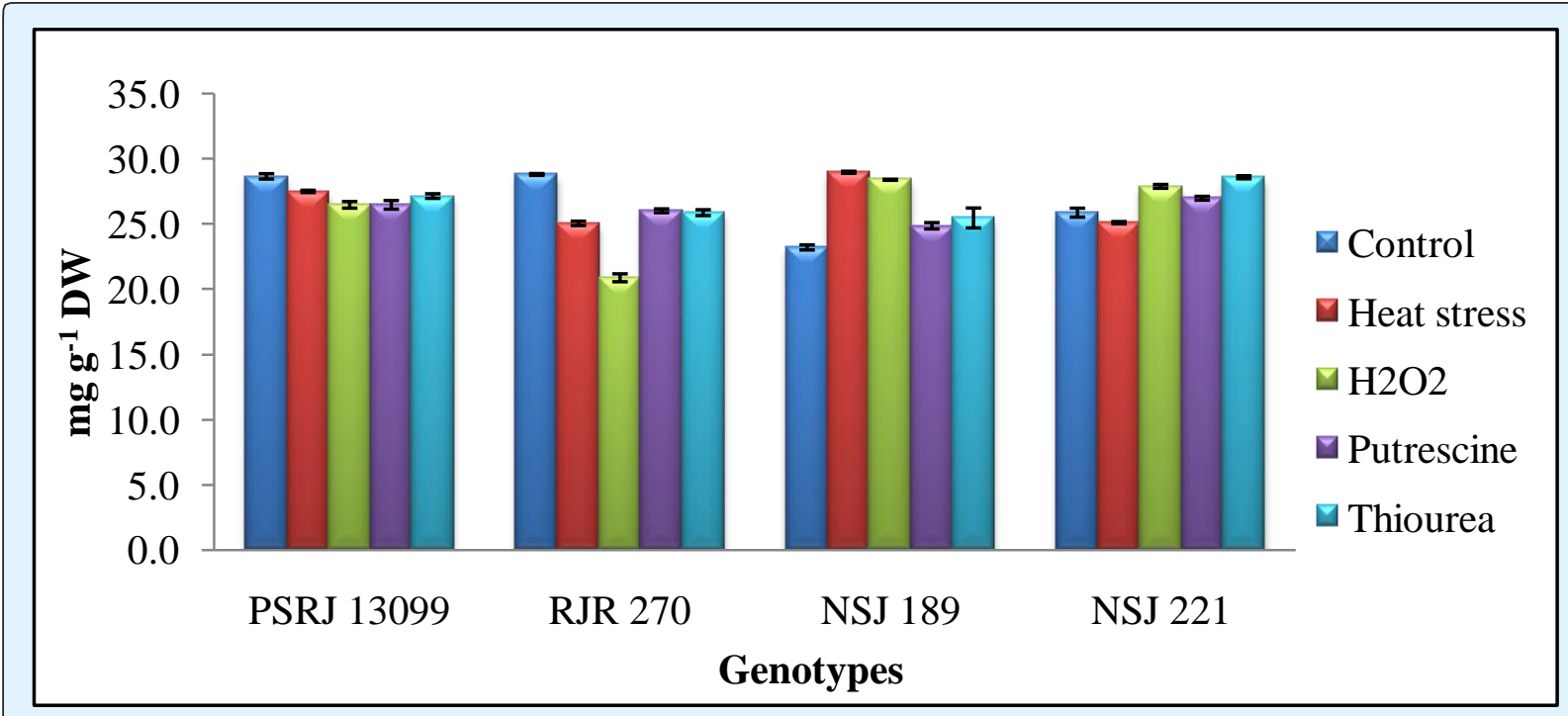

Figure 8: Quantification of total soluble proteins in maize seedlings upon exposure to high temperature stress. Prior to heat exposure seedlings were sprayed with $\mathrm{H}_{2} \mathrm{O}_{2}$, Putrescine and Thiourea.

\begin{tabular}{|c|c|c|c|c|c|}
\hline $\begin{array}{c}\text { Treatments/ } \\
\text { genotypes }\end{array}$ & PSRJ 13099 & RJR 270 & NSJ 189 & NSJ 221 & Mean \\
\hline Control & $28.63 \pm 28.63 \mathrm{ab}$ & $28.78 \pm 23.18 \mathrm{ab}$ & $23.18 \pm 28.78 \mathrm{j}$ & $25.85 \pm 25.85 \mathrm{ghi}$ & 26.61 \\
\hline Heat stress & $27.48 \pm 27.48 \mathrm{cde}$ & $25.03 \pm 28.94 \mathrm{hi}$ & $28.94 \pm 25.03 \mathrm{a}$ & $25.08 \pm 25.08 \mathrm{hi}$ & 26.63 \\
\hline $\mathrm{H}_{2} \mathrm{O}_{2}$ & $26.45 \pm 26.45 \mathrm{efg}$ & $20.86 \pm 28.37 \mathrm{k}$ & $28.37 \pm 20.86 \mathrm{abc}$ & $27.86 \pm 27.86 \mathrm{~cd}$ & 25.89 \\
\hline Putrescine & $26.45 \pm 26.45 \mathrm{de}$ & $25.99 \pm 24.84 \mathrm{ghi}$ & $24.84 \pm 25.99 \mathrm{ghi}$ & $26.95 \pm 26.95 \mathrm{ab}$ & 26.06 \\
\hline Thiourea & $27.12 \pm 27.12 \mathrm{efg}$ & $25.85 \pm 25.44 \mathrm{fgh}$ & $25.44 \pm 25.85 \mathrm{i}$ & $28.56 \pm 28.56 \mathrm{def}$ & 26.74 \\
\hline Mean & 27.23 & 25.3 & 26.16 & 26.86 & \\
\hline \multicolumn{7}{|c|}{ SED CD $(0.05) \mathrm{CD}^{(0.01)}$} \\
\hline \multicolumn{7}{|c|}{ Treatments $0.257^{*} 0.520^{*} 0.696^{*}$} \\
\hline \multicolumn{7}{|c|}{ Genotype x Treatments $0.515^{* *} 1.041^{* *} 1.393^{* *}$} \\
\hline
\end{tabular}

Table 8: Effect of foliar application of plant growth regulating chemicals on Protein content (mg g-1 DW) of maize genotypes under high temperature stress.

Means $\pm \operatorname{St} \operatorname{dev}(n=3)$ sharing with same letter did not differ significantly $\mathrm{P}<0.05$. Significant effects at $(P \leq 0.05)^{*}$ and $(P \leq 0.01)^{* *}$ of genotypes, treatments and their interaction. 


\section{Open Access Journal of Agricultural Research}

Thiourea application increased the protein content significantly. However, combined ANOVA concluded that the tolerant genotypes sprayed with Put, TU and $\mathrm{H}_{2} \mathrm{O}_{2}$ greatly increased the protein content control. It is observed to be vice-versa in susceptible genotypes. Maximum protein content was observed in heat stressed seedlings of NSJ 189 (28.94) followed by NSJ 221(28.56) with foliar application of TU. Increase in soluble protein in pollen of rice under heat stress was also observed by Tang et al. (2008) [53], which contributed to maintain cell structure and functions under stressed conditions. Mahatma et al. (2009) [38] reported increase in amino acid contents with the exogenous application of TU. Significant increase in amino acid contents with both seed treatment and foliar spray of TU has also been reported by Garg et al. (2006) [22]. Abdlkader et al., 2012 [54] reported that spraying of $2.5-5.0 \mathrm{mmol} \mathrm{TU}$ on wheat leaves at heading stage led to increase in photosynthetic pigments, antioxidant enzyme activity and metabolites including growth promoters. Mazid et al., 2011 [55] have reported regulation of $\mathrm{H}_{2} \mathrm{O}_{2}$ mediated abiotic stress tolerance in plants by nitric acid. Results in the present manuscript suggested that at vegetative stage foliar application of Put, TU and $\mathrm{H}_{2} \mathrm{O}_{2}$ improved the plant growth potential. This could be attributed to maintenance of redox homeostasis through its broad range of ROS scavenging antioxidant enzyme (SOD and POD) activities due to the sprayed chemicals.

\section{Conclusion}

Pretreatment of maize plants with different chemicals conferred protection of membrane integrity through reduced electrolyte leakage and MDA content and improved chlorophyll content, Fv/Fm and protein concentration. The induced heat stress tolerance response may be directly correlated with the regulated antioxidant enzyme activities and reduced lipid peroxidation and $\mathrm{H}_{2} \mathrm{O}_{2}$ levels. All the studied genotypes showed good improvement in various parameters over controls. Genotypes NSJ 221 and NSJ 189 possessed heat tolerant traits while genotypes PSRJ 13099 and RJR 270 susceptible to heat stress could mitigate the adverse affects of high temperature stress with the spray of Put, TU and $\mathrm{H}_{2} \mathrm{O}_{2}$. Stress alleviation was observed to be better with Put and TU. However, to validate further, the role of spray to alleviate heat stress in maize, field experiments need to be carried out to better understand the behavior of various genotypes exposed to high temperature stress.

\section{Acknowledgements}

This work was carried out under the National Innovations on Climate Resilient Agriculture (NICRA) project funded by Indian Council of Agriculture Research (ICAR), New Delhi, India. Authors are thankful to the InCharge, NBPGR Regional Station, Hyderabad for providing maize germplasm.

\section{References}

1. Almeselmani M, Deshmukh PS, Sairam RK (2009) High temperature stress tolerance in wheat genotypes: Role of antioxidant defense enzymes. Acta Agron Hung 57: 1-14.

2. Asada K (2006) Production and scavenging of reactive oxygen species in chloroplasts and their functions. Plant Physiol 141(2): 391-396.

3. Bala G, Caldeira K, Nemani R (2010) Fast versus slow response in climate change: implications for the global hydrological cycle. Climate Dynamics 35(2): 423-434.

4. Garg BK (2003) Physiological aspects of abiotic stress tolerance in arid legumes, In: Advances in Arid Legumes Research (Eds. A Henry, D Kumar and NB Singh). Scientific Publishers, Jodhpur, pp. 347-354.

5. Sairam RK, Rao KV, Srivastava GC (2002) Differential response of wheat genotypes to long-term salinity stress in relation to oxidative stress, antioxidant activity and osmolyte concentration. Plant Sci 163: 1037-1046.

6. Soliman WS, Fujimori M, Tase K, Sugiyama SI (2011) Oxidative stress and physiological damage under prolonged heat stress in C3 grass Lolium perenne. Grassland Sci 57(2): 101-106.

7. Thornton PK, Erickson PJ, Herrero M, Challinar AJ (2014) Climate variability and vulnerability to climate change: a review. Global Change Biology 20(11): 3313-332.

8. Karim MA, Fracheboud Y, Stamp P (2000) Effect of high temperature on seedling growth and photosynthesis of tropical maize genotypes. J Agron Crop Sci 184(4): 217-223. 


\section{Open Access Journal of Agricultural Research}

9. Ashraf M, Hafeez M (2004) Thermo tolerance of pearl millet and maize at early growth stages: growth and nutrient relations. Biol Plant 48(1): 8186.

10. Mittler R (2002) Oxidative stress, antioxidants, and stress tolerance. Trends Plant Sci 7(9): 405-410.

11. Xu S, Li J, Zhang X, Wei H, Cui L (2006) Effects of heat acclimation pretreatment on changes of membrane lipid peroxidation, antioxidant metabolites, and ultrastructure of chloroplasts in two cool-season turfgrass species under heat stress. Environ Exp Bot 56: 274-285.

12. Olaiya CO (2010) Pre-sowing bioregulator seed treatments increase the seedling growth and yield of Tomato (Solanum lycopersicon). J Plant Growth Regu 29(3): 349-356.

13. Perez-Adamor M, Miguel A, Leon J, Green M, Pamela J, et al. (2002) Induction of the arginine decarboxilase ADC2 gene provides evidence for the involvement of polyamines in the wound response in Arabidopsis. Plant Physiol 130(3): 1454-1463.

14. Pottosin I, Velarde-Buendía AM, Bose J, Zepeda-Jazo I, Shabala S, et al. (2014) Cross-talk between ROS and polyamines in regulation of ion transport across plasma membrane: implications for plant adaptive responses. J Exp Bot 65(5): 1271-1283.

15. Sahu MP, Kumawat SM, Ramaswamy NK, D'Souza SF, Singh G (2006) Sulphydryl bioregulator technology for increasing wheat productivity. Res Bull RAU-BARC 1-56.

16. Mathur N, Singh J, Bohra S, Bohra A, Vyas A (2006) Improved productivity of mung bean by application of thiourea under arid conditions. World J Agric Sci 2(2): 185-187.

17. Mani F, Bettaieb T, Zheni K, Doudech N, Hannachi C (2012) Effect of hydrogen peroxide and thiourea on fluorescence and tuberization of potato (Solanum tuberosum L.). J Stress Physiol Biochem 8: 61-71.

18. Amin AA, Abd El-Kader AA, Shalaby MAF, Gharib FAE, Rashad ESM, et al. (2013) Physiological effects of salicylic acid and thiourea on growth and productivity of maize plants in sandy soil. Commun Soil Sci Plant Anal 44(7): 1141-1155.
19. Nathawat NS, Nair JS, Kumawat SM, Yadava NS, Singh G, et al. (2007) Effect of seed soaking with thiols on the antioxidant enzymes and photosystem activities in wheat subjected to water stress. Biol Plant 51(1): 93-97.

20. Sahu MP, Solanki NS, Dashora LN (1993) Effects of thiourea, thiamine and ascorbic acid of growth and yield of maize (Zea mays L.). J Agron Crop Sci 171(1): 65-69.

21. Parihar GN, Sahu MP, Joshi NL (1998) Nitrogen, sulphur and thiourea nutrition of pearl millet [Pennisetum glaucum (L) R. Br.] II. Effect on yield and yield components. Ann Arid Zone 37(1): 59-67.

22. Garg BK, Burman U, Kathju S (2006) Influence of thiourea on photosynthesis, nitrogen metabolism and yield of clusterbean (Cyamopsis tetragonoloba (L.) Taub.) under rainfed conditions of Indian arid zone. Plant Growth Regul 48(3): 237-245.

23. Neill SJ, Desikan R, Hancock J (2002) Hydrogen peroxide signalling. Curr Opin Plant Biol 5(5): 388395.

24. Yadav SK, Tiwari YK, Singh V, Patil AA, Shanker AK, et al. (2016) Physiological and Biochemical Basis of Extended and Sudden Heat Stress Tolerance in Maize. Proc Natl Acad Sci India Sec B Biol Sci pp 1-15.

25. Yadav SK, Tiwari YK, Darala PK, Shanker AK, Jyothi Lakshmi N, et al. (2015) Genotypic Variation in Physiological Traits Under High Temperature Stress in Maize. Agric Res 5(2): 119-126.

26. Hodges DM, De Long JM, Forney C, Prange PK (1999) Improving the thiobarbaturic acid reactive substances assay for estimating lipid peroxidation in plant tissues containing anthocyanin and other interfering compounds. Planta 207(4): 604-611.

27. Velikova V, Yordanov I, Edreva A (2000) Oxidative stress and some antioxidant systems in acid raintreated bean plants: Protective role of exogenous polyamines. Plant Sci 151(1): 59-66.

28. Lichtenthaler HK (1987) Chlorophylls and carotenoids: Pigments of photosynthetic biomembranes. Methods Enzymol 148: 350-382. 


\section{Open Access Journal of Agricultural Research}

29. Giannopolitis CN, Reis SK (1997) Superoxide dismutase I. Occurrence in higher plants. Plant Physiol 59(2): 309-314.

30. Chance B, Maehly AC (1955) Assay of catalase and peroxidase. Methods Enzymol 2: 764-775.

31. Bradford MM (1976) A dye binding assay for protein. Anal Biochem 72: 248-254

32. Ranjeet RK, Sharma SK, Rai GK, Singh K, Choudhury $\mathrm{M}$, et al. (2014) Exogenous application of Putrescine at pre-anthesis enhances the thermotolerance of wheat (Triticum aestivum L.). Indian J Biochem Biophys 51(5): 396-406.

33. Jiang Y, Huang B (2000) Effects of drought or heat alone and in combination on Kentucky bluegrass. Crop Sci 40: 1358-1362.

34. Shi Q, Bao Z, Zhu Z, Ying Q, Qian Q (2006) Effects of different treatments of salicylic acid on heat tolerance, chlorophyll fluorescence and antioxidant enzyme activity in seedlings of Cucumis sativa L. Plant Growth Regul 48(2): 127-135.

35. Nayyar H, Chander S (2004) Protective effects of polyamines against oxidative stress induced by water and cold stress in chickpea. J Agron Crop Sci 190(5): 355-365.

36. Tadoline B (1988) Polyamine inhibition of lipoperoxidation. The influence of polyamines on iron oxidation in the presence of compounds mimicking phospholipid polar heads. Biochem J 249(1): 33-36.

37. Hui Guo D, Shu Y, Wen Juan L, De Hui X, Dong Hong $Q$ et al. (2006) Effects of exogenous spermidine on photosystem II of wheat seedlings under water stress. J Integrative Plant Biol 48(8): 920-927.

38. Mahatma MK, Bhatnagar R, Solanki RK, Mittal GK (2009) Effect of seed soaking treatment on salinity induced antioxidant enzymes activity, lipid peroxidation and free amino acid content in wheat leaves. Indian J Agric Biochem 22(2): 108-112.

39. Khalil SI, El-Bassiouny HMS, Hassanein RA, Mostafa HA, El-Khawas SA, et al. (2009) Antioxidant defence system in heat shocked wheat plants previously treated with arginine or putrescine. Aust J Basic Appl Sci 3(3): 1517-1526.
40. Wahid A, Sehar S, Perveen M, Gelani S, Basra SMA, et al. (2008) Seed pretreatment with hydrogen peroxide improves heat tolerance in maize at germination and seedling growth stages. Seed Sci Technol 36(3): 633645.

41. Hernandez JA, Jimenez A, Mullineaux P, Sevilla F (2000) Tolerance of pea (Pisum sativum L.) to long term salt stress is associated with induction of antioxidant defences. Plant Cell Environ 23(8): 853862.

42. Gong M, Chen B, Li ZG, Guo LH (2001) Heat-shockinduced cross adaptation to heat, chilling, drought and salt in maize seedlings and involvement of $\mathrm{H}_{2} \mathrm{O}_{2}$. J Plant Phyisol 158(9): 1125-1130.

43. Sharma KM, Sharma DD, Sukhla KB, Upadhyaya B (2008) Growth partitioning and productivity of wheat as influenced by fertilization and foliar application of bio-regulator. Indian J Plant Physiol 13 (4): 60.

44. Emmanuel ESC, Vignesh V, Kumar BA, Marathamuthu S (2010) Bioaccumulation and physiological impact of rare earth elements on wheat (Triticum aestivum). Indian J Plant Physiol 15: 177-180.

45. Morales D, Rodrigues P, Bellamico J, Nichotes E, Torrecillas A, et al. (2003) High temperature preconditioning and thermal shock imposition affects water relations, gas exchanges and root hydraulic conductivity in tomato. Biol Plant 47: 203-208.

46. Edwards GE, Baker NR (1993) Can CO2 assimilation in maize leaves be predicted accurately from chlorophyll fluorescence analysis? Photosynth Res 37(2): 89-102.

47. Chakraborty U, Pradhan D (2011) High temperatureinduced oxidative stress in Lens culinaris, role of antioxidants and amelioration of stress by chemical pre-treatments. J Plant Interact 6(1): 43-52.

48. Bavita A, Akash D (2011) Thermo tolerance and Antioxidant response induced by purtrescien and heat acclimation in wheat seedlings. Seed Science and Biotechnology. Global Sci Book 5(1): 42-46.

49. Zhu J-K (2001). Plant salt tolerance. Trends Plant Sci 6(2): 66-71.

Yadav SK, et al. Exogenous Application of Bio-Regulators for Alleviation of Heat Stress in Seedlings of Maize. J Agri Res 2017, 2(3): 000137. 


\section{Open Access Journal of Agricultural Research}

50. Kumar SV, Sharma ML, Rajam MV (2006) Polyamine biosynthetic pathway as a novel target for potential applications in plant biotechnology. Physiol Mol Biol Plants 12: 3-28.

51. Parida AK, Das AB (2005) Salt tolerance and salinity effects on plants: a review. Exotoxicol Environ Saf 60(3): 324-349.

52. Aldasoro JJ, Matilla, Nicolás G (1981) Effect of ABA, fusicoccin and thiourea on germination and $\mathrm{K}^{+}$and glucose uptake in chickpea seeds at different temperatures. J Plant Physiol 53(2): 139-145.

53. Tang G, Tang X, Mendu V, Jia X, Chen QJ, et al. (2008) The art of microRNA: Various strategies leading to gene silencing via an ancient pathway. Biochim Biophys Acta 1779(11): 655-662.
54. Abdelkader AF, Hassanein R, Ali H (2012) Studies on effect of salicylic acid and thiourea on biochemical activities and yield production in wheat (Triticum aestivum var. Gimazaq) plant growth under drought stress. African J Biotech 11 (64): 12728-12739.

55. Mazid M, Khan TA, Mohammad F (2011) Role of nitric oxide in regulation of $\mathrm{H}_{2} \mathrm{O}_{2}$ mediating tolerance of plants to abiotic stress: a synergistic signaling approach. J Stress Physiol Biochem 7: 34-74. 